\title{
SCIENTIFIC BASIS
}

OF INNOVATION ACTIVITY

https://doi.org/10.15407/scine16.04.003

OSIPOV, A.F., and CHERNENKO, K.V.

Kyiv National University of Construction and Architecture, 31, Povitroflotsky Ave., Kyiv, 03037, Ukraine,

+380 442415580 , knuba@knuba.edu.ua

\section{INFORMATION MODEL OF THE PROCESS OF LIFTING A LONG-SPAN ROOF}

Introduction. Development of information systems allows creating, modelling and improving technological solutions of lifting and assembling long span roofs.

Problem Statement. Development of new organizational and technological solutions, technologies and methods requires a complex research at the initial stages of their creation with the help of software. These studies help to avoid problems and misleading that may occurs as a result of worong decisions.

Purpose. To substantiate organizational and technological decisions in the development of new technology of lifting long span roofs, by creating an information model of the process for lifting long span roofs with certain detalization to analyze the components of the process, conditions and disadvantages that occurs when using the new technology of lifting long span roofs.

Materials and Methods. Research and development of information model of the process of lifting large-scale coverings with the help of newly created load-lifting walking modules. A method for simulating the process, conditions, and objects involved in lifting large-scale coatings was used.

Results. In the process of modelling based on the proposed information model of the process, organizational and technological peculiarities of the use of new technology of lifting long span roofs with simultaneous arrangement of permanent supports and determined values of the experimental values were considered as a certain series-discrete order of visual images and parameters.

Conclusions. Creating an information model of the process, which essentially belongs to the class of imitation models has allowed significantly reducing the time and substantiate the organizational and technological decisions while development of new technology. This has enabled not only comparing and identifying the conditions under which such technology has significant advantages over existing ones, but also improving it.

Keywords: information modelling, long span roofs, lifting, information model, information-visual model, simulation-visual modeling method.

The modern economic development of Ukraine is based on social doctrine that provides for the systematic implementation of $R \& D$ achievements aiming at further significant improvement of technological resources of the social sphere, urban development, and infrastructure. Manufacturing industries and consumer services have been showing a steady trend towards expansion and complication, there are new industries and services that

Citation: Osipov, A.F., and Chernenko, K.V. Information Model of the Process of Lifting Long-Span Roof. Sci. innov. 2020. V. 16, no. 4. P. 3-10. https://doi.org/10.15407/scine16.04.003 
require the development of new, sometimes, unique spatial planning and design solutions for buildings and structures, as well as their rapid implementation in the practice of industrial and civil engineering.

The construction of large-scale industrial and public buildings is growing especially fast, as a result of rapid development, primarily, of transport and agricultural infrastructure in Ukraine. However, such buildings and structures are characterized by extreme technological parameters, which is caused by a unique spatial planning and design solutions of these buildings and difficult conditions of construction works. The process of construction of long-span buildings is rather complicated and requires significant labor inputs, mostly, at height. Therefore, to reduce the share of elevated jobs, long-span buildings are usually mounted by large blocks. However, the enlargement of blocks is limited by the capacity of transport infrastructure and cranes, as well as technological difficulties related to the organization of erection sites and other factors.

Alternative solutions during the construction of long-span buildings include the so-called "craneless erection methods" that use a variety of cable and hydraulic hoist systems. These methods involve the use of special hoisting equipment integrated into the engineering system, with the erection process realized under the control of an automated control system.

Thus, "craneless erection methods" belong to complex functional systems, the design methodology of which involves either systematic research in order to determine the functional of the system and, accordingly, multi-stage modeling in order to determine the structural and functional configurations, or the use of the results of operation and application of similar systems (the so-called method of designing technical systems "from achieved") [2].

While developing and substantiating fundamentally new methods of erection, it is almost impossible to carry out design "from what has been achieved". Therefore, the creation of new met- hods for implementation and means of mechanization of the processes of lifting long-span roofs is among the tasks of designing new complex technological systems and requires comprehensive and time-consuming system research and modeling. Given the dimension of the problem, there is a need to use modern software and information technology that can interact with complex information models.

In Ukraine and worldwide, large-scale research is underway and problems related to the construction of large-scale buildings and structures are being solved, which have been comprehensively described by Heino Engel [3] and Prof. D.F. Honcharenko [4]. V.I. Torkatiuk [5], O.O. Ignatenko [6], Yu.T. Sobka [7] and other authors have dealt with research and development of technologies for lifting large-scale roofs using the "craneless methods".

Functional capabilities of information modeling have been considered in researches of A.S. Bilyk, M.A. Beliaev [8], and O.V. Levchenko [9]. The object of modeling in these and other studies, as a rule, are the design processes related to buildings, structures, and their parts. However, the problems related to modeling construction processes in their dynamics using the latest information technologies have remained understudied.

Thus, there is a problem in substantiating and developing a new technology for lifting large roofs using newly created lifting walking modules that belong to the class of new complex technological systems, which can be solved by creating an information model of the construction process of lifting large roofs.

The main direction of information modeling is the creation of digital models of objects with different levels of detail, which allows improving, controlling, and correcting errors and shortcomings while modeling/designing. In the construction industry, this approach is called building information modeling or BIM. It has just begun to be implemented in Ukraine. BIM is the process of creating a building model that, depending on the tasks, is visualized with different levels of detail. 


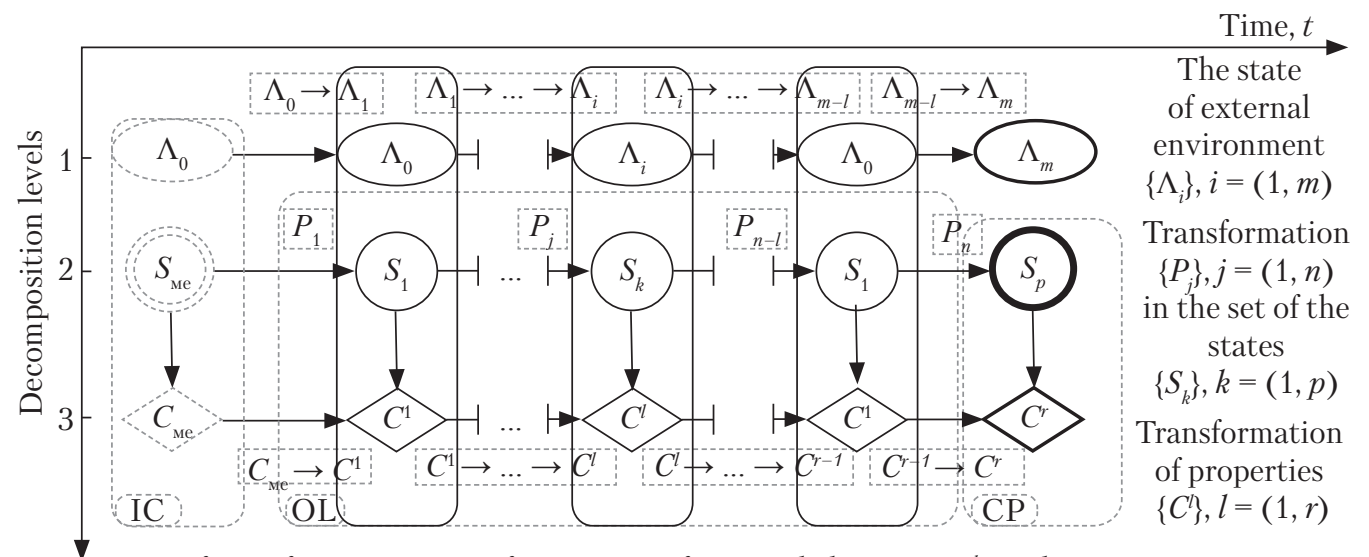

Set of transformations $\left\{P_{j}\right\}$ of properties of material elements $\left\{C^{l}\right\}$ in the set of their states $\left\{S_{k}\right\}$ and external factors $\left\{\Lambda_{i}\right\}$

Fig. 1. The process of creating construction products $(\mathrm{CP})$ as sequential discrete transformations of the properties of objects of labor (OL) [2]: IC is initial conditions

With sufficient detail, the digital model is converted into a digital copy of the future building or structure.

A digital copy of construction object is a parameterized "replica" of a construction object that makes it possible to present spatial planning and design features and to preserve its physical, technical, and other properties in digital format.

To create a digital copy of the construction object, there are used modern software packages enabling the formation of a digital copy of the construction object with required level of detail. A digital copy of a high-detail construction object creates the necessary conditions for information modeling of all construction (technological) processes related to the construction of object.

Information modeling of construction processes is substantiation and development of a system of gradual, dynamic transformations that are fixed by means of visual images and parameters and allow illustrating the technological process and settling contradictions that arise when modeling fundamentally new systems. The modeling process is to simulate construction processes, organizational and technological solutions and simple operations within a digital model or a copy of the construction site and the operator's workplace, which makes it possible to determine, to compare, and to forecast technical and economic indicators of different options and, accordingly, to choose the most effective one.

For modeling purposes, it is necessary to determine the parameters of each method, process, technique, operation, which are required for their full operation and execution. The creation of such processes can take into account different levels of detail and data. For example, at the initial stages of modeling, only a few parameters are used to reduce the number of options, and as it has been done, the number of parameters increases, which enables speeding up the modeling and fully reproducing the process at each stage of construction.

The information model of the construction process is presented in the form of a system of visual images and parameters. Visual images make it possible to clearly understand where the workforce and mechanisms are located in space and time, which allows more efficient organization of operator workspace, placement of technological equipment and mechanisms, and so on.

The theoretical framework for developing an information model of any construction process is the assumption that construction process [2], as a manufacture of building products, is a set of sequential discrete transformations of material ele- 


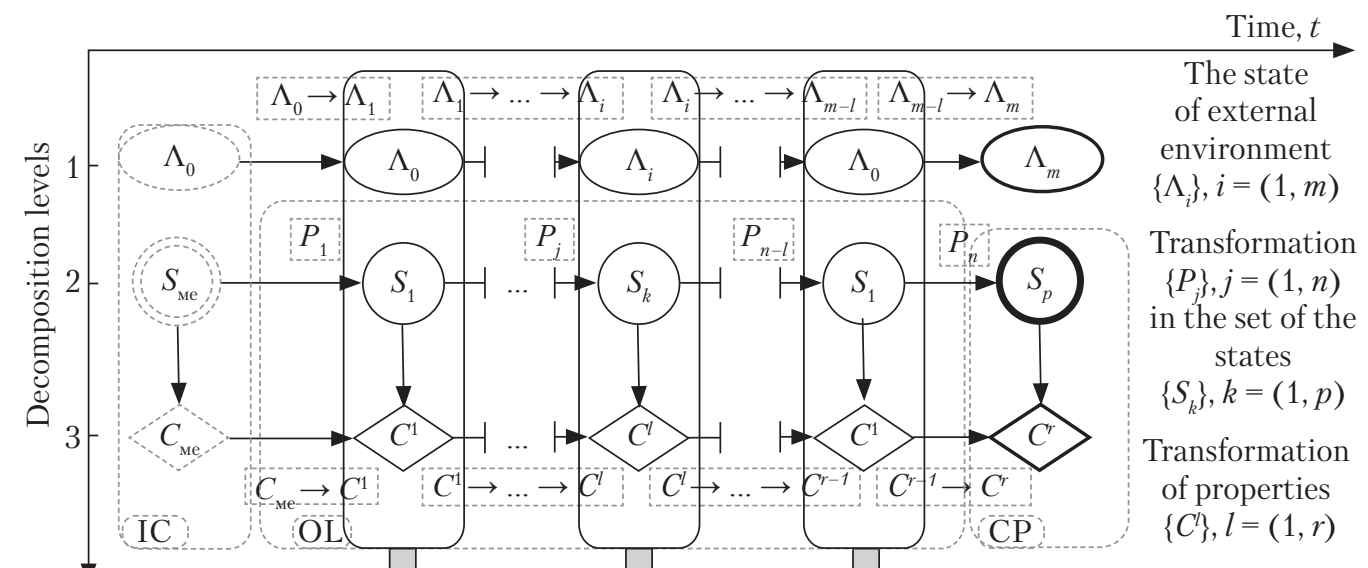

V Set of transformations $\left\{P_{j}\right\}$ of properties of material elements $\left\{C^{l}\right\}$ in the set

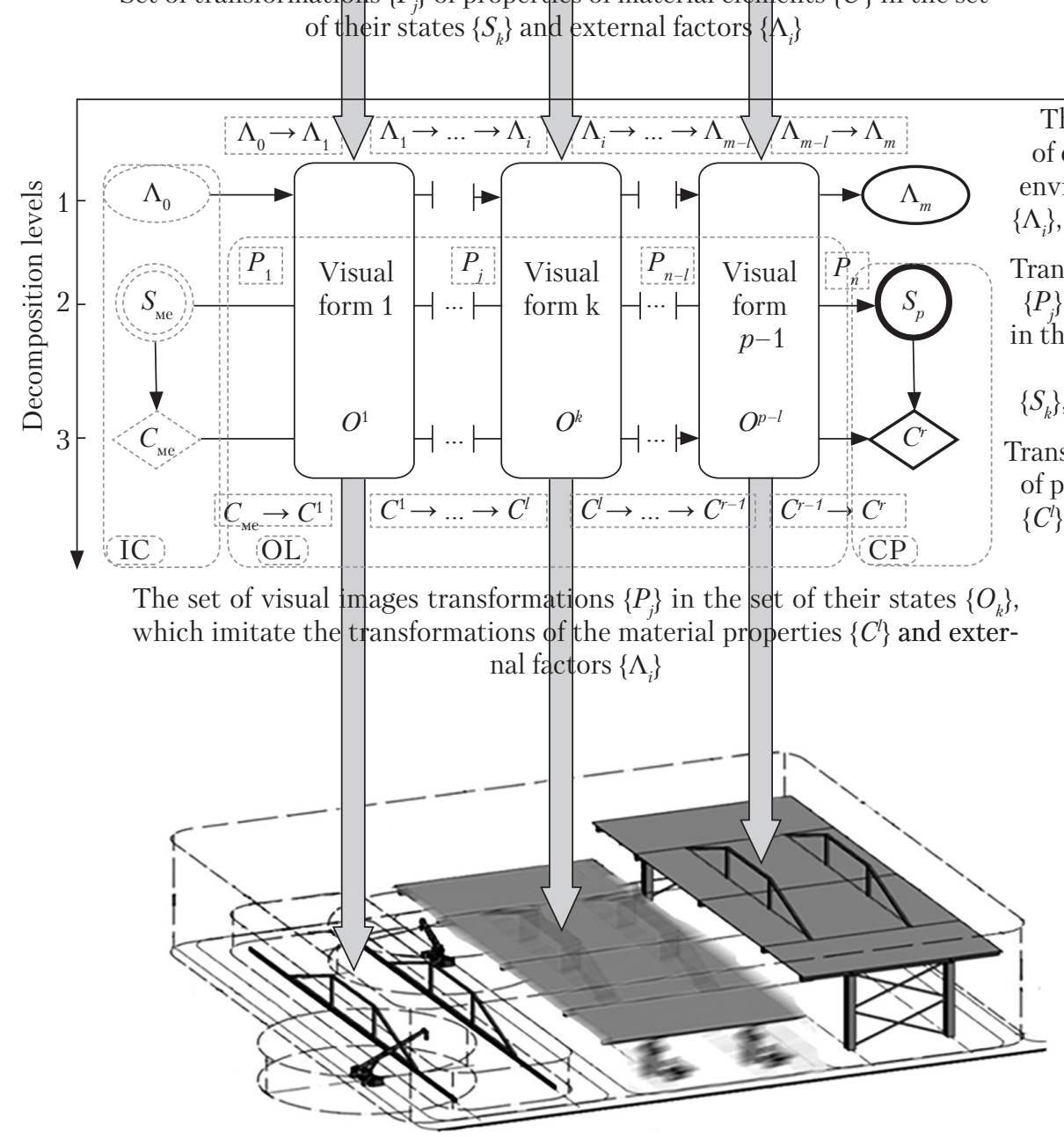

Fig. 2. The process of creating construction products as sequential discrete transformations of visual images $\left(O^{k}\right)$ (by example of developing a new technology for lifting large roofs) 
ments $\left\{P_{j}\right\}$ Each transformation irreversibly changes the original properties of material elements (internal processes and phenomena $\left\{C^{l}\right\}$ ) and the parameters of external environment $\left\{\Lambda_{i}\right\}$, i.e. the conditions of construction process (Fig. 1).

Thus, the process of creating construction products is sequential discrete transformation of the properties of material elements $\left(C^{l} \rightarrow C^{r}\right)$ from their initial state $S_{\text {ме }}$ (characterized by initial properties of material elements $C_{\text {ме }}$ and initial conditions of external environment $\Lambda_{0}^{\mathrm{me}}$ ) to the final one $S_{\mathrm{sp}}$ that determines design properties of construction products $C_{\mathrm{sp}}$, with each $k$-th state of material elements $S_{k}$ corresponding to a certain $l$-th property $C^{l}$, and to each $j$-th transformation $P_{j}$ and with the state of material elements $S_{k}$ corresponding to the $i$-th state of the environment $\Lambda_{i}$, which is determined by the respective set of factors.

The theoretical model of construction process can be presented in the form of the following formalized model [2]:

$$
\left(\forall, P_{j}\right)\left[\begin{array}{r}
\left(S_{k} \rightarrow S_{p}\right) ; \\
\exists !\left(C^{l} \rightarrow C^{r}\right) ; \\
\left(\Lambda_{i} \rightarrow \Lambda_{m}\right) ;
\end{array}\right]
$$

showing that for any transformation $P_{j}$ from the set of possible transformations $P_{j} \in\left\{P_{j}\right\}^{j}$ there are common sets of respective transformations (changes) of the states $\left(S_{k} \rightarrow S_{p}\right)$, properties $\left(C^{l} \rightarrow C^{r}\right)$ of material elements, and the conditions of external environment $\left(\Lambda_{i} \rightarrow \Lambda_{m}\right)$.

Thus, the construction process is formed as a set of sequential discrete transformations $\left\{P_{j}\right\}$ that exist in the set of states of material elements $\left\{S_{k}\right\}$ and the set of external factors $\left\{\Lambda_{i}\right\}$ that affect the process.

Given the above, the target sequential discrete series of visual images and parameters under stu$d y$ is proposed to use as information model of the construction process. The model can be attributed to the class of simulation models. Let us call it the visual simulation model. In this case, the simulation process is referred to the visual simulation method.

Then, the process of creating construction products (Fig. 1) is formed as a certain order of

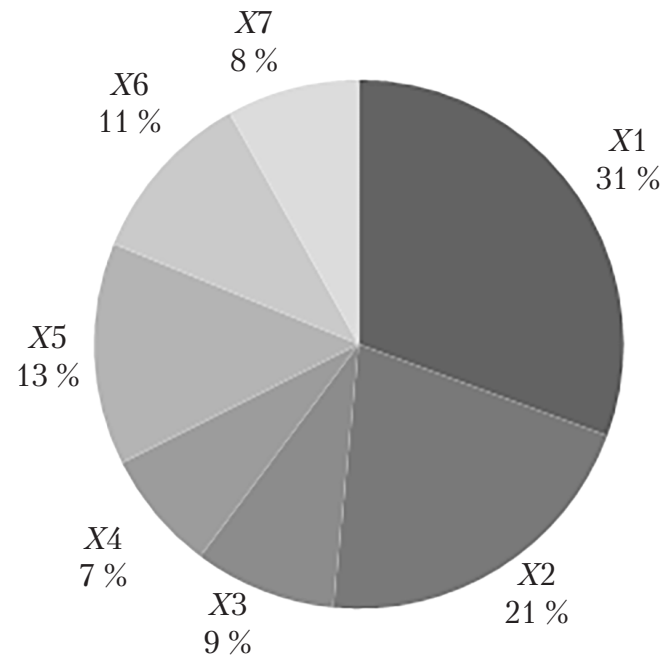

Fig. 3. The parameters ranked according to the results of expert survey [10]: $\mathrm{X} 1$ is weight of the roof block, $\mathrm{X} 2$ is maximum lifting range, $\mathrm{X} 3$ is dimensions of the roof block, $\mathrm{X} 4$ is average duration of roof erection works, $\mathrm{X} 5$ is average productivity of roof erection, $\mathrm{X} 6$ is energy consumption per hour, $\mathrm{X} 7$ is the average number of workers

sequential discrete transformations of visual images and parameters under study (Fig. 2).

In this model, the visual images Ok describe the state of material elements $S_{k}\left(O_{k} \asymp S_{k}\right)$ and the process of their transformation simulates the transformation of the properties of material elements $\left\{C^{l}\right\}$ in the set of external factors $\left\{\Lambda_{i}\right\}$.

Then, the visual simulation model of the construction process can be presented in the form of the following formalized model:

$$
\left(\forall, P_{j}\right)\left[\begin{array}{r}
\left(O_{k} \rightarrow O_{p}\right) ; \\
\text { 日! }\left(C^{l} \rightarrow C^{r}\right) ; \\
\left(\Lambda_{i} \rightarrow \Lambda_{m}\right) ;
\end{array}\right]
$$

Showing that for any transformation of visual image of process $P_{j}$ from the set of possible transformations $P_{j} \in\left\{P_{j}\right\}$, there are common sets of respective transformations (changes) of the visual images $\left(O_{k} \rightarrow O_{p}\right)$, properties $\left(C^{l} \rightarrow C^{r}\right)$ of material elements, and the conditions of external environment $\left(\Lambda_{i} \rightarrow \Lambda_{m}\right)$.

Thus, the visual simulation model of the construction process reproduces the state of material elements (objects of labor), while the process of 

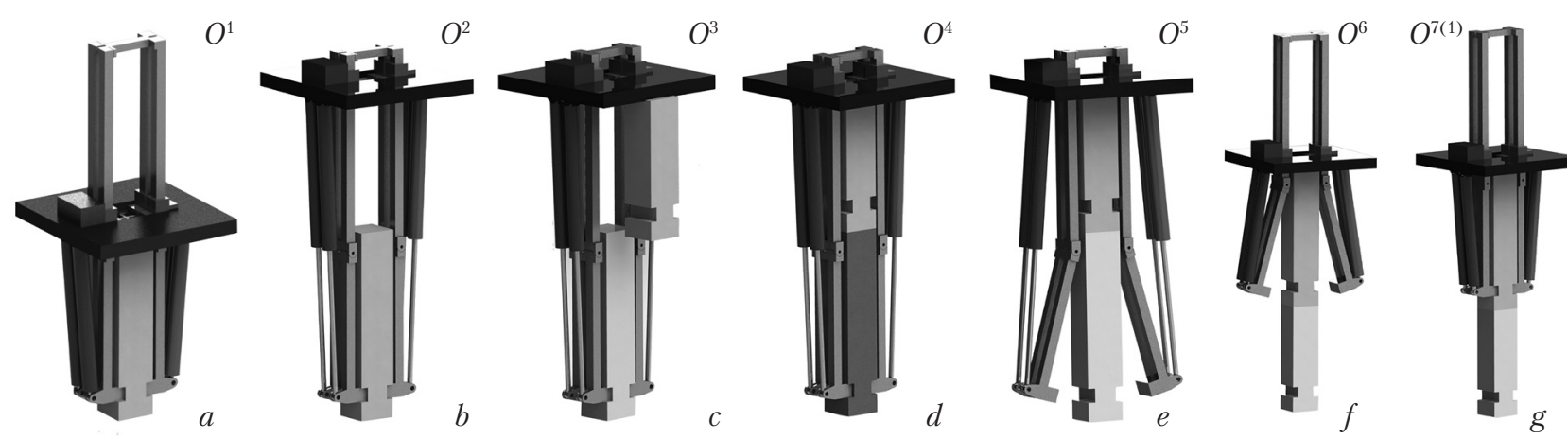

Fig. 4. Visual images $\left(O^{k}\right)$ describing the states of the load-lifting walking module in the set of the working operation cycle [10]: a) the initial state; b) the roof is lifted for a push step; c) erection of the next support element; d) the element is erected, anchored, the roof rests on supports (columns); e, f) switching the jacks to the next position; g) the initial state of the next cycle

its transformation (simulation) deals with changes in the properties of objects of labor and environmental conditions.

To create an visual simulation model of the process of lifting large-scale roofs, the main spatial planning and structural solutions of buildings and structures, which are typical for objects with large roofs have been identified [3]. Such buildings and structures include those with the supports of load-bearing frames distanced more than $30 \mathrm{~m}$ from each other (the distance can reach $200 \mathrm{~m}$ ). Based on the analysis of such buildings and structures, a digital model typical for large-span buildings with large roofs has been created.

To compare the organizational and technological solutions of the methods for lifting large roofs, 16 different methods of lifting large roofs are grouped and studied [10] according to their characteristics and indicators of manufacturability. The main indicators of manufacturability, as defined by the method of expert evaluation (Fig. 3), which are sufficient to compare the organizational and technological solutions of methods for lifting large roofs are as follows: weight of the roof block, maximum lifting range, dimensions and volume of the roof block, average duration of erection, average productivity of roof erection, tonnage factor, energy inputs, and energy consumption per one hour. Having studied and compared this information, a new erection technology has been proposed. It allows the simultaneous lifting of large roofs heavier than 1000 tons to a height of $27.4 \mathrm{~m}$ and more.

The peculiarity of this technology is as follows: having assembled a large roof within the site area, on low scaffolding, the large roof is lifted by pushing it out with special jack systems, load-lifting walking modules (LLWM) [11], with simultaneous installation of columns by their step-by-step extension. This has reduced the number of timeconsuming processes to be done at height. The cycle of lifting a large-scale roof with walking modules has the following main components [12]:

- elevation of an assembled large-scale roof to a required height given the stroke length of the jack rod and its load capacity;

- erection and working fastening of the column element;

- alignment of structural elements;

- anchorage of the column element and temporary transfer of load from the roof to the erected column element, except for the last cycle, where the column with roof is fully fixed;

- retraction of the jack rod to the initial position and leaning upon the mounted support elements. These operations are repeated cyclically until the roof reaches the design elevation, after which the LLWM is completely or partially dismantled.

Solidworks and Compass software is used to create a digital model of the process of lifting lar- 
ge-scale roofs with load-lifting walking modules. The parameters of technology and technical solution of load-lifting walking modules have been worked out and optimized by the visual simulation method through building a system of target sequential discrete series of visual images (Fig. 4) with the required level of detail.

While developing and substantiating the new technology for lifting large roofs using LLWM, it was necessary to compare it with the above-mentioned conventional methods for lifting large roofs. To do this, a pre-created digital model of the building has been developed using the software package Autodesk Revit. With its help, the erection works have been simulated using modern computer systems such as Autodesk Navisworks, and others, as well as Microsoft Project software to build a Gantt chart, based on which a typical cyclogram of the process of lifting a large roof has been created.
Hence, in the course of this research, the theoretical framework for creating an information model of the construction process as a certain sequential discrete order of visual images and parameters studied has been considered. The model belongs to the simulation class and is called by the authors "the visual simulation model of the construction process". The very simulation process is respectively called "the visual simulation method". Thanks to the application of this model and method, a new technology of lifting largescale roofs has been developed using newly created load-lifting walking modules that make it possible to work out its technical and technological parameters and to justify the feasibility of use. The visual simulation model can be used for simulating any construction process, with the help of newly created complex technological systems: robotic complexes, mobile combines, etc.

\section{REFERENCES}

1. Chernenko, V. K., Osypov, O. F., Tonkacheiev, H. M., Romanushko, Ye. H., Nazarenko, I. I., Cherep, V. I., ... Osypov, S. O. (2011). Technology of installation of building structures. Kyiv: Horobets. [in Ukrainian].

2. Osypov, A. F. (2016). Adaptive dynamically transforming technological systems. Methodology for designing organizational and technological solutions for the reconstruction of buildings. Kyiv: Komprynt [in Russian].

3. Heino Engel. (2007). Structure Systems. Stuttgart: Hatje Cantz.

4. Honcharenko, D., Evel, S., Zubko, H., Starkova, O. V. (2013). Construction and reconstruction of stadiums. Kharkiv: Koloryt [in Russian].

5. Torkatiuk, V. Y. (1985). Installation of structures of large-span buildings. Moskov: Strojyzdat [in Russian].

6. Yhnatenko, A. A., Hluschenko, Y. V. (1992). Development of coating lifting technology with hydraulic lifting devices. Industrial construction and engineering structures, 26-27 [in Russian].

7. Sobko, Yu. T., \& Chernenko, V. K. (2016). Research of the main technological indicators influencing craneless methods of lifting of structural coverings. New Technologies in Construction, 31, 50-58 [in Ukrainian].

8. Bilyk, A. S., Beliaiev M. A. (2015). Overview of opportunities and prospects in Ukraine. Industrial Construction and Engineering Structures, 2, 9-15 [in Ukrainian].

9. Levchenko, O. V. (2015). BIM - information modeling of buildings in Autodesk software products. Modern problems of architecture and urban planning, 25, 81-86 [in Ukrainian].

10. Osypov, O. F., Chernenko, K. V. (2014). Research of technological processes of consolidation and lifting of large-size coverings with use of load-lifting walking modules. Management of complex systems development, 19 [in Ukrainian].

11. Patent of Ukraine N 76242. Chernenko K. V., Rashkivskyj V. P. Device for cover mounting comprises bearing elements [in Ukrainian].

12. Patent of Ukraine N 76241. Chernenko K. V., Rashkivskyj V. P. Method for mounting cover of a building [in Ukrainian].

Received 27.08.19

Revised 02.12.19

Accepted 17.02.20 
О.Ф. Осипов, К.В. Черненко

Київський національний університет будівництва і архітектури, просп. Повітрофлотський, 31, Київ, 03037, Україна, +380 442415580 , knuba@knuba.edu.ua

\section{ІНФОРМАЦІЙНА МОДЕЛЬ ПРОЦЕСУ ПІДНІМАННЯ ВЕЛИКОРОЗМІРНИХ ПОКРИТТІВ}

Вступ. Розвиток інформаційних систем сьогодні дозволяє створювати принципово нові та удосконалювати наявні технологічні рішення й методи піднімання великорозмірних покриттів.

Проблематика. Розробка нових організаційно-технологічних рішень, технологій та методів вимагає системних і комплексних досліджень ще на початкових етапах їхнього створення за допомогою сучасних програмних комплексів. Такі дослідження необхідні для усунення недоліків, які можуть виникнути як результат хибних рішень.

Мета. Обгрунтувати організаційно-технологічні рішення при розробці нової технології піднімання великорозмірних покриттів шляхом створення інформаційної моделі процесу піднімання великорозмірного покриття певної деталізації для аналізу складових процесу, умов та недоліків, що виникають при використанні нової технології зазначеного процесу.

Матеріали й методи. Дослідження і розробка інформаційної моделі процесу піднімання великорозмірних покриттів за допомогою знову створюваних вантажопідйомних крокуючих модулів. Використано імітаційно-візуальний метод моделювання процесу, умов та об’єктів, що проходять та задіяні при підніманні великорозмірних покриттів.

Результати. В процесі моделювання на основі запропонованої інформаційної моделі процесу, як певний послідовнодискретний порядок візуальних образів та параметрів, що досліджуються, було розглянуто організаційно-технологічні особливості використання нової технології піднімання великорозмірних покриттів із одночасним влаштуванням постійних опор та визначено величини дослідних параметрів.

Висновки. Створення інформаційної моделі процесу, яка за суттю належить до класу імітаційних моделей, дозволило значно скоротити час та обгрунтувати прийняті організаційно-технологічні рішення при розробці нової технології. Це дало змогу не тільки порівняти та визначити умови, за якими зазначена технологія має значні переваги над вже наявними, але й у процесі моделювання удосконалити ii.

Ключові слова: інформаційне моделювання, великорозмірні покриття, монтаж, інформаційно-візуальна модель, імітаційно-візуальний метод моделювання. 